\title{
トータルドライレジストプロセスの展望
}

\author{
服 部 秀 三 \\ 名古屋大学工学部電子機械工学科 $\overline{\mathbf{T}} 464$ 名古屋市千種区不老町 \\ (1984 年 11 月 10 日受理)
}

\section{A Review of Total Dry Resist Process}

Shuzo HATTORI

Nagoya University Department of Electronic Mechanical Engineering

(Received November 10, 1984)

\begin{abstract}
A progress of total dry resist process for e-beam lithography using plasma polymerization for resist casting and plasma etching for development, mostly by our group, is reviewed. i) Use of flow type reactor, ii) copolymerization of e-beam sensitive monomer with etch-resistive monomer, iii) sensitization by high-z atom, and iv) use of hydrogen plasma for development gave rise to a great extent of e-beam sensitivity which finally reached to $5 \mu \mathrm{C} / \mathrm{cm}^{2}$. A modeling study of dry development have shown a linear dependence of logalithmic film thickness change to the logalithmic scission fraction per monomer unit, $\lambda$. A 0.15 of $\lambda$ is found to be necessary which figure will explain observed decrese of e-beam sensitivity by dry development from that by wet development. Several way to improve dry devlopment process and also dry devlopable X-ray resign is discussed on the basis of knowleges so far obtained.
\end{abstract}

\section{1. はじめに}

VLSI の集積度が増し，基準線巾が小さくなるに従っ て，プロセス信頼度を保つために，プロセスのドライ 化, プロセスの低温化, 平担構造のためのプロセスなど プロセス技術の高度化が必要となる。プロセスのドライ 化は，ドライエッチング，イオン注入が標準のプロセス となるに及んでプロセス全体がドライ化できると考えら れ，一部の洗條プロセスやリソグラフィープロセス（レ ジストプロセス）が取残された形となった。

Table 1 はリソグラフィープロセスのドライ化の歴 史の要約である。著者等は,レジスト成膜プロセスにプ ラズマ重合を用いるととによってトータルドライレジス トプロセスの完成を目ざし，手始めにマスクプロセスの トータルドライ化のために Fig. 1 の装置を試作して研 究を開始した。Table 2 はドライプロセスとウェットプ ロセスの功罪をレジストプロセスを中心に比較したもの である。マスクプロセスに関しては, トータルドライレ ジストプロセスの研究はほぼ目標を達したかに思われ
る。しかし年ら, 此の研究は電子線リソグラフィーに限 られたため, 現在では特殊な場合を除いて，そのま〉ウ ェハプロセスに適用されるととはないと考えられる。何 故ならば, 研究開始当初の予想に反して, 電子線リソグ ラフィーは，描画データ転送速度を高くすることが高価 な技術となるため設備経費 1 億円当りのスループットが 経済的要求を満す程度まで上らないことが明らかになっ たからである。

ウエハ用のリソグラフィープロセスのドライ化は, 今 後ホトリソグラフィー或いはX線リソグラフィーを目標 として進められることになるであろうが, 本稿ではこれ までの電子線リソグラフィーのドライ化に関する研究の あとを振り返って，その中で，ホトリソグラフィー或い はX線リリソグラフィープロセスのドライ化についての 手掛りを求めることにする。

\section{2. プラズマ重合電子線レジストの感度}

Table 3 は著者等の研究室で試みられた主なプラズ マ重合電子線レジストの感度の一覧表である。 
Table 1 Histrical review of all dry resist process.

\begin{tabular}{|c|c|c|}
\hline Transfer & Develop & Casting \\
\hline 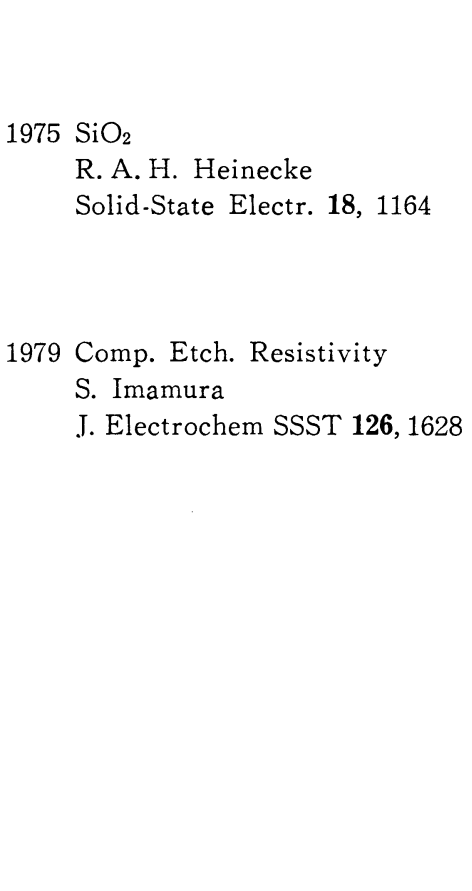 & 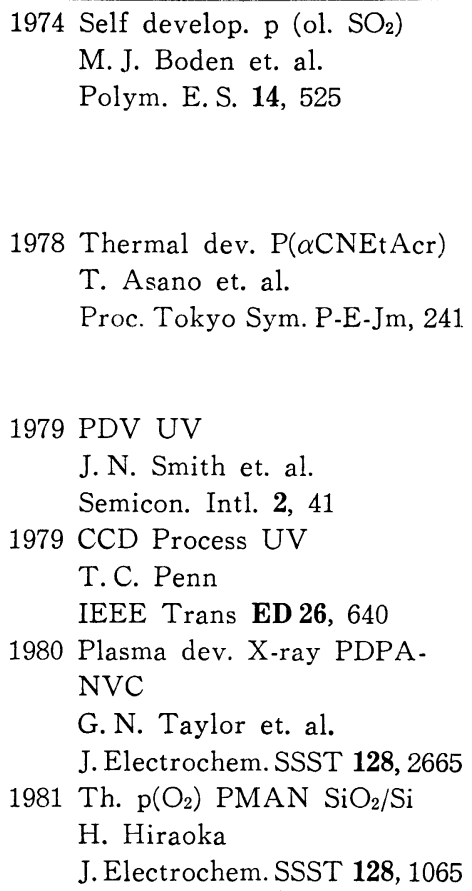 & $\begin{array}{l}1980 \text { PPMMA } \mathrm{CCl}_{4} \mathrm{Pl} \mathrm{Cr} \\
\text { S. Morita et. al. } \\
\text { J. Appl Phys 51, } 3938 \\
1981 \text { PPMMA (Fl) Ar }-\mathrm{O}_{2} \mathrm{Pl} \\
\text { J. Tamano et. al. } \\
\text { P. Chem. P. Proc. } \mathbf{1}, 261\end{array}$ \\
\hline
\end{tabular}

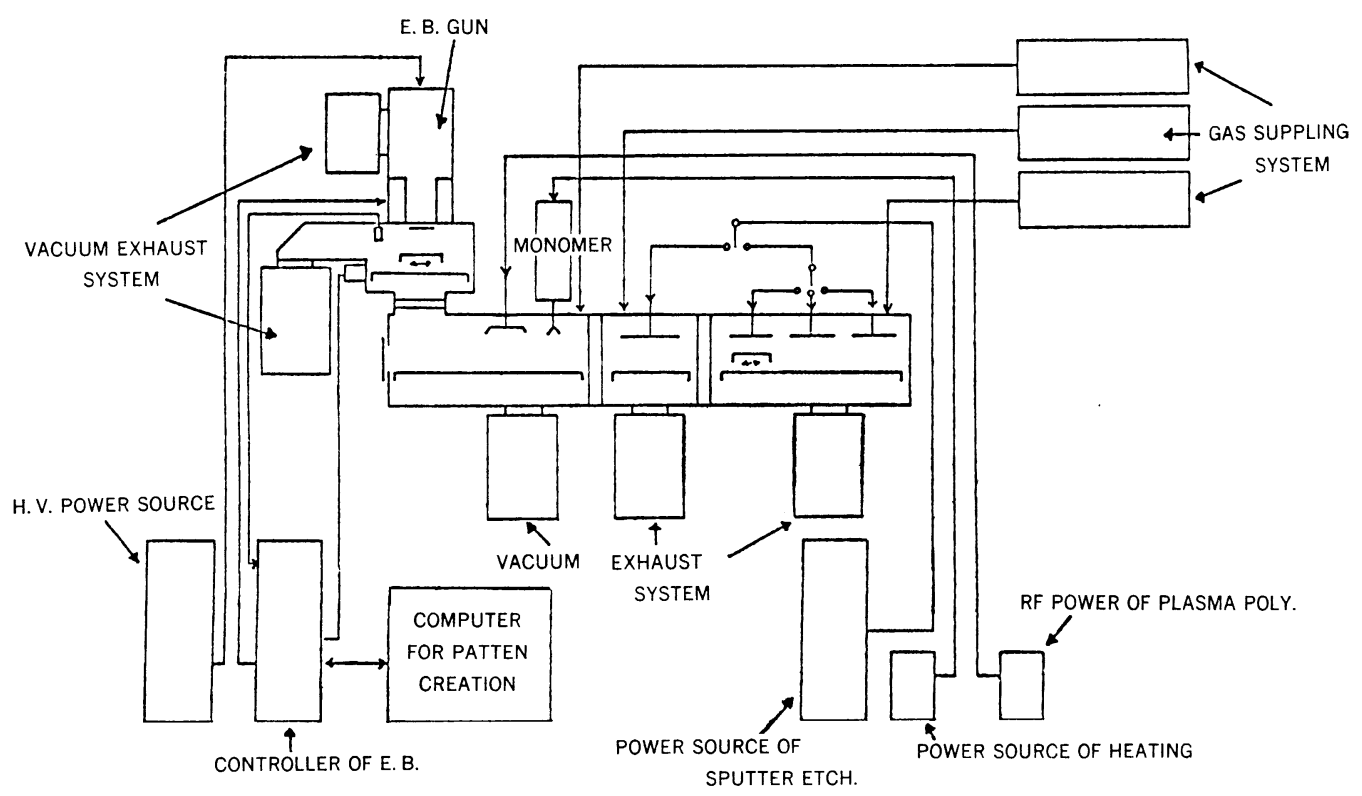

Fig. 1 A super precision vacuum lithography apparatus. 
Table 2 Merits \& demerits of dry process.

\begin{tabular}{llll}
\hline General & Transfer & Develop & Coating \\
\cline { 2 - 4 } Reduce & Directional & Avoid Swelling & Fast R \& D \\
Utility & Etching & & \\
Environmental & & Handy for \\
Safety & & Process \\
Controllability & & Engineers \\
& & Feasibility \\
& & for Complex \\
Expensive & & Structure \\
Instrument & & \\
\hline
\end{tabular}

Table 3 Sensitivety improvement of plasma-polymerized e-b resist.

\begin{tabular}{clllc}
\hline $\begin{array}{c}\text { Types of } \\
\text { Reactor }\end{array}$ & \multicolumn{1}{c}{ Monomer } & $\begin{array}{c}\text { Polymerization } \\
\text { Plasma }\end{array}$ & $\begin{array}{c}\text { Developing } \\
\text { Plasma }\end{array}$ & Sensitivity \\
\hline $\begin{array}{c}\text { Parallel } \\
\text { Plate }\end{array}$ & MMA & MMA & $\mathrm{CCl}_{4}$ & $>10^{4}$ \\
Flow & MMA & $\mathrm{Ar}$ & $\mathrm{Ar}+\mathrm{O}_{2}$ & $10^{3}$ \\
Flow & MMA+Sty & $\mathrm{Ar}$ & $\mathrm{Ar}+\mathrm{O}_{2}$ & $10^{2}$ \\
Flow & MMA+TMT & $\mathrm{Ar}$ & $\mathrm{Ar}+\mathrm{O}_{2}$ & 20 \\
Flow & 6FBMA+Sty & $\mathrm{Ar}$ & $\mathrm{H}_{2}$ & $10^{2}$ \\
Flow & 6FBMA+Sty+TMT & $\mathrm{Ar}$ & $\mathrm{H}_{2}$ & 5 \\
\hline
\end{tabular}

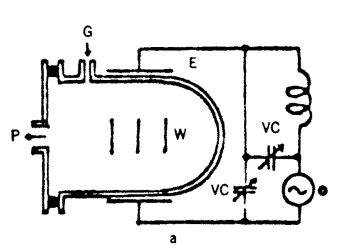

Outer Electrode $\mathrm{C}$-couple

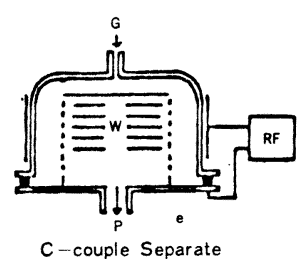

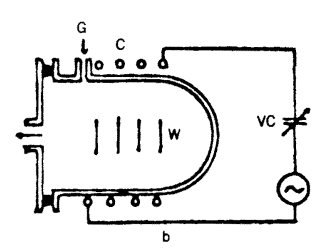

Outer Electrode L-couple

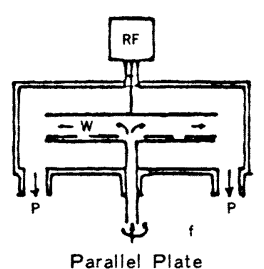

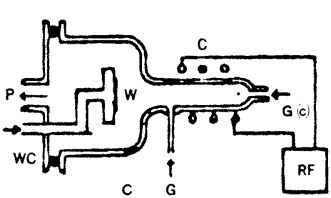

$L$-couple Flow

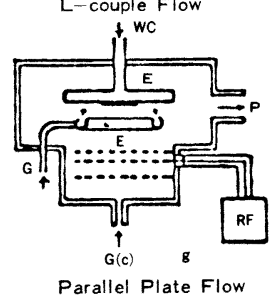

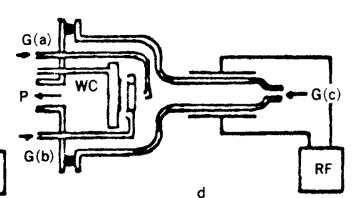

C couple Flow Multiple Inlet:

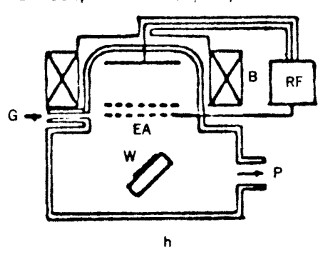

Ion Shower Apparatus

Fig. 2 Various RF plasma reactors

a : Outer electrode C-couple ; b : Outer electrode L-couple ; : C-couple flow ; $\mathrm{d}$ : C-couple flow (multiple inlet); e : C-cople separate; $f$ : Parallele plate reactor ; $:$ Parallel plate flow; $h$ : Ion shower appratus

P : Pump; W : Water; G : Gas inlet; E : Electorode; WC : Cooling water ; B : B Field ; RF : RF power supply ; EA : Accellerating E; G(a): Momomer gas inlet ; G(c) : Carrier gas inlet

表に見られるような $10^{3}$ 以上の感度の改善は，i ）反応 装置を平行平板型からフロー型に変更した。ii）電子線 感度の高い高分子とプラズマエッチ耐性の高い高分子と の共重合, 吕) 原子量の大きい金属原子を混入すること による増感, iv) $\mathrm{Ar}+\mathrm{O}_{2}$ プラズマから $\mathrm{H}_{2}$ プラズマに 現像プロセスを変更した, という4つの効果によって達
成された。

平行平板型とフロー型の反応装置は, Fig. 2 の $\mathrm{f}$ c にそれぞれ示されるような装置で，平行平板型に於て は基板がプラズマ中に浸漬されていて原料モノマーがプ ラズマ平中で分解され易く, 又基板上に成長した重合膜 はイオンの衝撃によって架橋の程度を増すのに比して, 
Table 4 Method of preparation polymer character condition resist property.

\section{Plasma Polymerization \\ highly $x$-linked} Parallel Plate

fragmented

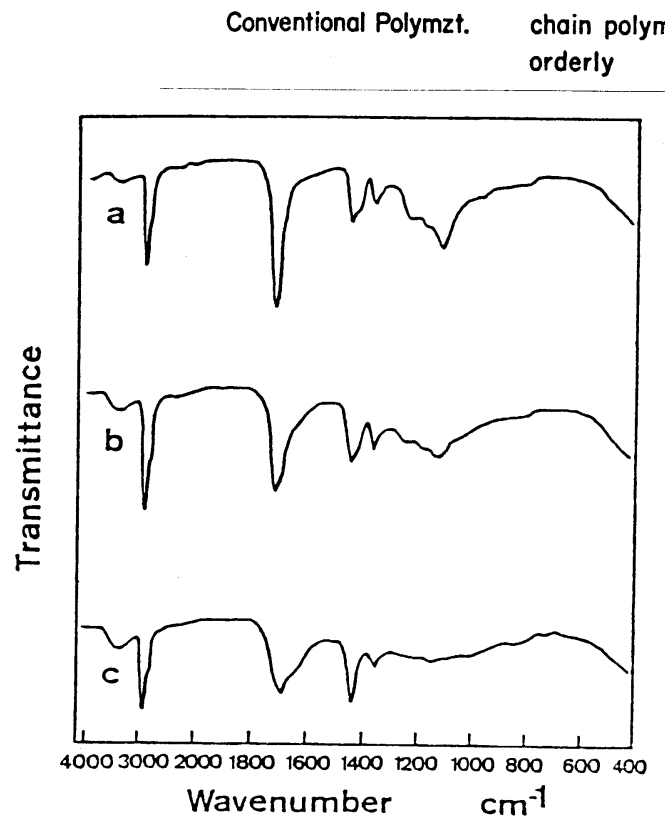

Fig. 3 The dependence of IR absorption spectra on the gas flow rate of argon at 0.7 Torr and 10 watts : (a) $77 \mathrm{~cm}^{3} \mathrm{STP} / \mathrm{min}$, (b) $63 \mathrm{~cm}^{3} \mathrm{STP} /$ $\mathrm{min}$, and (c) $42 \mathrm{~cm}^{3} \mathrm{STP} / \mathrm{min}$.

フロー型に於ては，プラズマは主としてキャリヤガスの 励起種を生成するのに用いられて, プラズマ領域の下流 に流入するモノマーの大部分はそのま〉基板に達し，キ ヤリヤガスの励起種によって作られた励起中間生成物と 共に基板上で重合するので, 重合膜は原料をモノマーの 形状を保存した高分子から成り，架橋も中程度である。

反応装置之重合条件による生成重合膜の性質の差は Table 4 亿まとめられている。同じフロ一型反応装置 を用いてあ，キャリヤガス流量が小さいか電力密度が 高いほど重合膜の性質は平行平板型装置による重合膜 のそれに近く，その反対の重合条件では重合膜の性質は 通常の方法で重合された高分子のそれに近くなる。

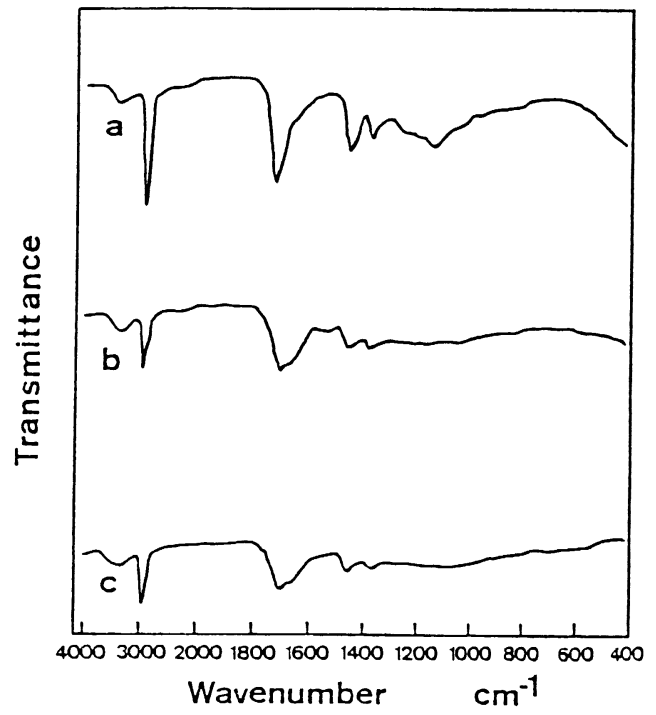

Fig. 4 The dependence of IR absorption spectra on the discharge power at $0.7 \mathrm{Torr}, 63 \mathrm{~cm}^{3}$ $\mathrm{STP} / \mathrm{min}$ (ar) and $6.3 \mathrm{~cm}^{3} \mathrm{STP} / \mathrm{min}$ (MMA): (a) 10 watts, (b) 20 watts, and (c) 30 watts.

Fig. 3 及び Fig. 4 は，キャリヤガス流量を変えたと き及び電力を変えたときのプラズマ重合 MMA の赤外 スペクトルであって上述の事情を示している。

重原子による増感は，TMT（四メチル錫）の共重合 によって行われた。5\%（モル）の TMT は顕著な電子 線感度の向上を屯たらす。錫を高分子中に取入れること は，合成技術の上で必ずし屯容易ではないのだが，プラ ズマ重合に於ては原料モノマー気体中に TMT の気体 を混入するだけで実に容易に実現する。

共重合の効果，水素プラズマエッチの効果については その理由は明確ではないが，エッチング現象の機構に関 係しているので，次章に触れることにする。 


\section{3. ドライ現像の機構}

前章に述べたように，プラズマ重合成膜プラズマエッ チ現像電子線レジストは十分な感度を与えるととがわか ったが，プラズマエッチ現像は電子線レジストの解像力 の低下をむたらすととがわかって来たので，その理由を つきとめるための研究が行われた。

\section{1 ドライ現像のモデル考察}

i ) 直鎖高分子に対して, 1 モノマー単位当り $\lambda$ の確 率でランダムな主鎖切断が生じ，ガウス型初期分子量分 布を出発点として分子量分布の変化を計算する。ii）蒸 気圧が $p_{v}$ 以上になる低分子はすべて気化して膜外に去 ることによって規格化(体積)膜減り $V(\lambda)$ が定まる。と いう仮定で電子線による自己現像特性を計算してみ た。図 5 は $\lambda$ の增加に伴う分子量分布の変化を示す。分 子量分子はモノマー単位で測った長さ $n$ の関数として

$$
N(n, \lambda)=e^{-\pi \lambda} N(n, 0)+e^{-n \lambda} \int_{n}^{\infty} N\left(n^{\prime}, 0\right) d n^{\prime}
$$

で与えられる。入は電子線ドーズ $D$ から

$$
\lambda=\frac{M_{0}}{\bar{M}_{f}}=M_{0} \frac{E G_{S} D}{100 g z \rho A}
$$

の如く求められる。 $E$ は電子当り吸収エネルギー $(\mathrm{eV})$ $G S$ は吸収エネルギー $100 \mathrm{eV}$ 当り切断確率, $z \rho$ は平方 $\mathrm{cm}$ 当りの膜重量, $M_{0}$ はモノマ一分子量 $\bar{M}_{f}$ は数平均 分子量, $A$ はアボガドロ数である。 $V(\lambda)=1$-(残膜率) は, 蒸気圧 $p:$ を与える分子を $n_{v}$ オリゴマーとして

$$
V(\lambda)=n \int_{0}^{n_{v}} n \cdot N(n, \lambda) d n
$$

から求められる。 $p$ は $n$ の関数として経験式

$$
p_{v}=B T^{1 / 2} \exp \left\{1-(1.5)^{\left.\log _{2} n_{v} E /(k T)\right\}}\right.
$$

で与えられるが, MMA オリゴマーについては， $B=$ $2.1 \times 10^{11}$ (dynes $\mathrm{cm}^{-2} \mathrm{~K}^{-1 / 2}$ ), $E=7.3 \times 10^{-13}$ (ergs $\left.\mathrm{mol}^{-1}\right)$ を用いた。

MMA に対する計算の結果は Fig. 5 のごとに曲線 を与える。 $p_{v}$ としは $1 \mathrm{~m}$ Torr を用いた。Fig. 6 を みると電子線自己現像特性は

$$
V(\lambda)=c \cdot \lambda^{\alpha}
$$

で良く近似されることがわかる。 $\alpha$ は MMA について は 1.2 .3 が得られた。式 $(5)$ は溶液現像の溶解度 $R$ を 与える式

$$
R=R_{0}+\beta\left(\lambda / M_{0}\right)^{\alpha}
$$

ときめて良く似ている。但し溶液現像の場合は $\alpha$ が高 分子の構造 (時に側銷) と溶媒との組み合せによって変 るのに対して，電子線自己現像の場合は一定值である。 又, 溶液現像の場合 $\lambda=0.015$ 付近で MMA について は分子量 6000) で $R_{0}>\beta\left(\lambda / M_{0}\right)$ となって現像加能に

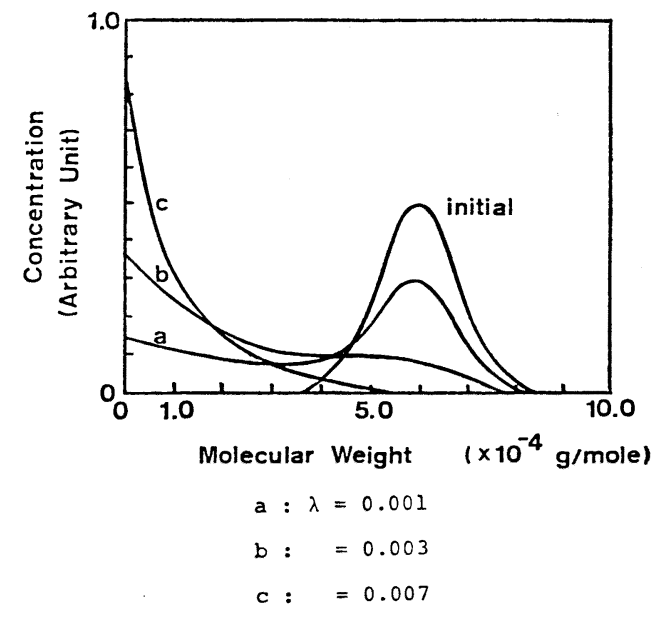

Fig. 5 Change of number average molecular weight distribution function for various random scision fraction, starting from Gaussian initial distribution.

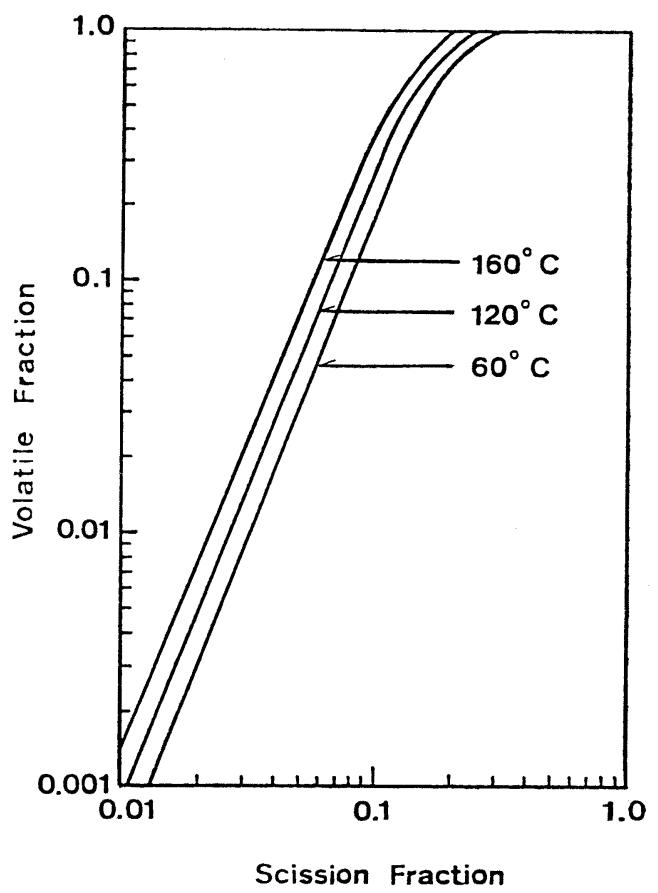

Fig. 6 Dependence of volatile fraction of polymer layer on random scission fraction.

なるのの比べて, 電子線自己現像では $\lambda=0.15$ (6-オリ ゴマー) になって始めて現像可能となる。

\section{2 実験との比較}

Fig. 7 は, PMMA についての電子線自己現像特性 が（図中O) 式(5)によってよく説明されることを示し ている。又 Fig. 8 は他のプラズマ重合電子線レジス 


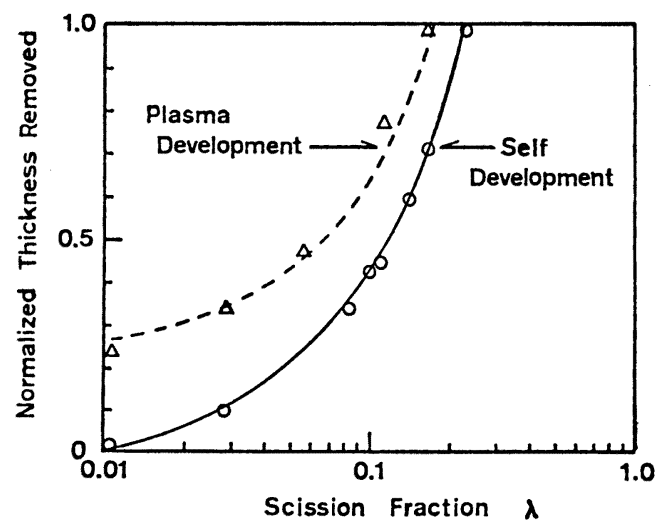

Fig. 7 Theoretical and experimental dry development characteristics, - Theoretical self development, $\cdots . .$. Theoretical plasma development, O Experimental self development, $\Delta$ Experimental plasma development.

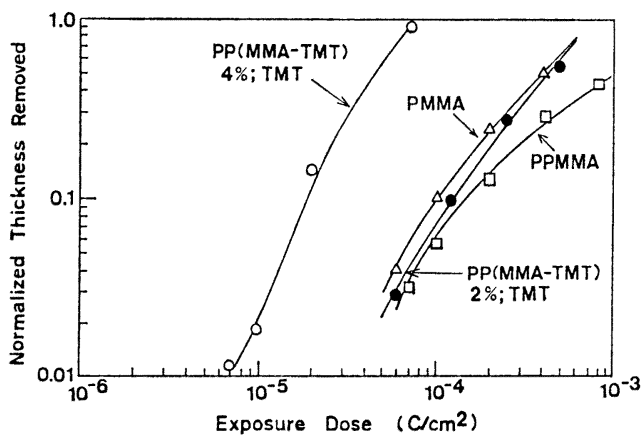

Fig. 8 Experimental self development characteristics.

トの自己現像特性を示すが，乙の特性を直線で近似すれ ば，やはり式(5)があてはまる。

さらに興味あるととは, PMMA について電子線描画 後プラズマエッチ現像した場合の現像特性 (図中 $\triangle$ ) が, 自己現像の場合と同じ $\alpha$ を用いて

$$
V_{d}(\lambda)=C \cdot\left(\lambda+\lambda_{d}\right)^{\alpha}
$$

で (図中破線) で良く説明されることである。(Fig. 7 の場合は $\left.\lambda_{d}=0.05\right)$ このととは，プラズマエッチの効 果が，電子線の効果と同質で主鎖の切断の程度を增すこ とになることを意味している。式（7)の関係を再度両対 数グラフ上の直線で近似して

$$
V_{d}(\lambda)=C\left(\lambda+\lambda_{d}\right)^{\alpha} \approx c / \lambda^{A}
$$

とすると $A$ は $\alpha$ に比べて小さい数字となる。このとと はプラズマエッチ現像が, 低い解像力を与えることを説 明している。云いかえれば，描画プロセスの効果之現像 プロセスの効果が加算的である限り良い解像力を与えな いことがわかる。

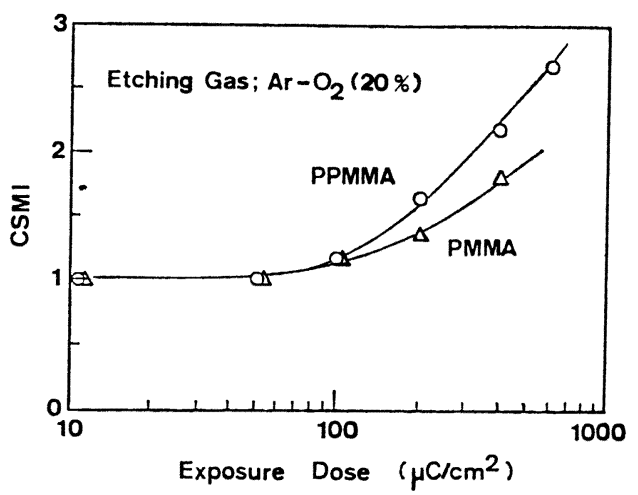

Fig. 9 Chemical structure modification index (CSMI) for plasma-polymerized methylmethacrylate (PPMMA) and poly methylmethacrylate (MMA).

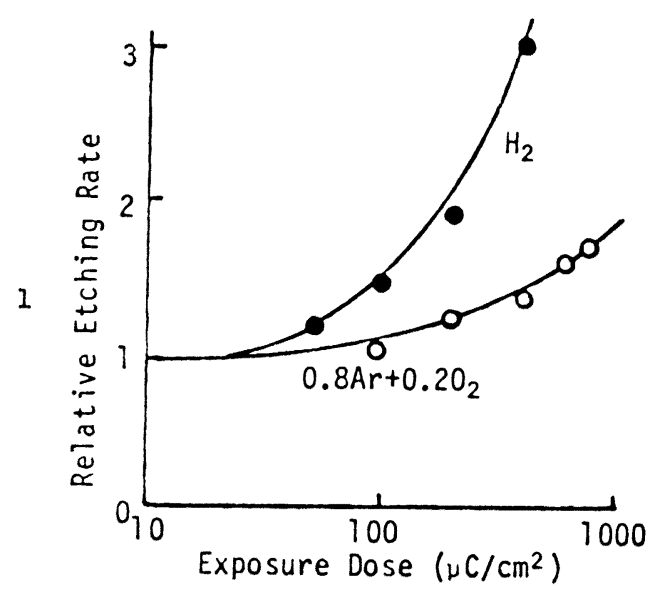

Fig. 10 Effect of plasma etching gas on the resist development.

実験で得られた現像勃果之式 ( 7 )の与える現像効果の 比を化学作用指数 CSMI と定義すると.

$$
\mathrm{CSMI}=\frac{c\left\{\left(\lambda+\lambda_{d}\right)^{\alpha}-\lambda^{\alpha}\right\}}{\left[V_{d}(\lambda)\right]_{\mathrm{exp}}-c \lambda^{\alpha}}
$$

CSMI は現像効果之電子線効果の加算性加らの外れ，も しくは主鎖切断以外の電子線の化学変化の目安を与え る。その一例はFig. 9 のごとく, プラズマ重合 PMMA と通常の PMMA にあらわれる。

前章で実験事実に触れた, 対エッチ性高分子之高電子 線感度高分子の共重合の効果も, 現像効果之電子線効果 の加算性からの外れに関係して理解されねばならない。 スチレンと $50 \%$ 共重合の MMA は未照射部分では PMMA の約 4 倍の耐プラズマエッチ性を有する。所が この共重合膜が PMMA の 7 分の 1 の電子線ドーズで プラズマエッチ現像されるというととは, 40 モノマー単 
位程度の分子量まで電子線によって分子量が低下したと きに，PMMA と同程度の対プラズマエッチ性まで下が るととを意味する。一方気化現像完了の $\lambda_{v}=0.15$ の 7 分の 1 のと末照射部を $25 \%$ 減膜するに必要な $\lambda_{p}=$ 0.048 の和 $\lambda+\lambda_{d}=0.069$ では現像完了の $38 \%$ しか説 明できない。
水素プラズマによる現像の効果についても同様のとと が言える。Fig. 10 は PMMA に対する水素プラズ マのエッチ速度と $20 \%$ 酸素混入アルゴンプラズマのエ ッチ速度を比較したものである。水素プラズマに対して は, 分子量変化が,（気化現像の分子量の 1 析上の分子 量で）エッチ速度に影響を及ぼすのである。

Table 5 Plasma polymerization parameter of multiple layer film.

\begin{tabular}{|c|c|c|c|c|c|c|c|}
\hline $\begin{array}{l}\text { Discharge frequency } \\
\text { Discharge power } \\
\text { Flow rate of } \mathrm{Ar}\end{array}$ & & & $\begin{array}{l}13.56 \mathrm{MHz} \\
20 \mathrm{~W} \\
500 \mathrm{SCCM}\end{array}$ & & & & \\
\hline $\begin{array}{r}\text { Monomer }\left(\mathrm{M}_{3}\right) \\
\left.\quad \text { source }\left(\mathrm{S}_{3}\right)\right)\end{array}$ & MMA & MA & $\begin{array}{l}\text { MMA } \\
+5 \% \mathrm{TMT}\end{array}$ & $\begin{array}{l}\text { MMA } \\
+5 \% \mathrm{TMT}\end{array}$ & MMA & MMA & MMA \\
\hline Flow rate & 200 & 300 & 100 & 100 & 200 & 200 & 200 \\
\hline Gas pressure & 13.3 & 16 & 13.3 & 13.3 & 14 & 14 & - \\
\hline Discharge duration (min) & 5 & 10 & 20 & 15 & 5 & 10 & - \\
\hline $\begin{array}{r}\text { Monomer }\left(\mathrm{M}_{2}\right) \\
\quad\left(\text { source }\left(\mathrm{S}_{2}\right)\right)\end{array}$ & - & - & - & - & $\mathrm{MA}$ & $\mathrm{S}$ & $\mathrm{S}$ \\
\hline Flow rate & - & - & - & - & 300 & 150 & 150 \\
\hline Gas pressure & - & - & - & - & 16 & 13.3 & 17 \\
\hline Discharge duration (min) & - & - & - & - & 5 & 5 & 6 \\
\hline $\begin{array}{r}\text { Monomer }\left(\mathrm{M}_{1}\right) \\
\left.\quad \text { (source }\left(\mathrm{S}_{1}\right)\right)\end{array}$ & $\begin{array}{l}\text { MMA } \\
+5 \% \mathrm{TMT}\end{array}$ & $\begin{array}{l}\text { MMA } \\
+5 \% \mathrm{TMT}\end{array}$ & $\begin{array}{l}\text { MMA } \\
+50 \% \mathrm{~S}\end{array}$ & $\begin{array}{l}\text { MMA } \\
+10 \% \mathrm{MIPK}\end{array}$ & $\begin{array}{l}\text { MMA } \\
+5 \% \mathrm{TMT}\end{array}$ & $\begin{array}{l}\text { MMA } \\
+5 \% \mathrm{TMT}\end{array}$ & $\begin{array}{l}\text { MMA } \\
+5 \% \mathrm{TMT}\end{array}$ \\
\hline Flow rate & 100 & 100 & 100 & 100 & 100 & 100 & 100 \\
\hline Gas pressure & 13.3 & 13.3 & 13.3 & 13.3 & 13.3 & 13.3 & 13.3 \\
\hline Discharge duration (min) & 5 & 5 & 20 & 30 & 5 & 5 & 4 \\
\hline Repeat cycle & 3 & 4 & 3 & 3 & 3 & 2 & 3 \\
\hline Film thinkness & 2500 & 4000 & 12000 & 6000 & 2500 & 5000 & 5000 \\
\hline
\end{tabular}

Table 6 Plasma etching parameter and etching rate.

\begin{tabular}{|c|c|c|c|c|c|c|}
\hline Discharge frequency & \multicolumn{3}{|l|}{$13.56 \mathrm{MHz}$} & \multicolumn{3}{|l|}{ 13. $56 \mathrm{MHz}$} \\
\hline Discharge power & \multicolumn{3}{|l|}{$50 \mathrm{~W}$} & \multicolumn{3}{|l|}{$50 \mathrm{~W}$} \\
\hline Etching gas & \multicolumn{3}{|c|}{$\mathrm{Ar}+40 \% \mathrm{O}_{2}$} & \multicolumn{3}{|l|}{$\mathrm{CCl}_{4}$} \\
\hline Gas pressure & \multicolumn{3}{|l|}{ 13. $3 \mathrm{~Pa}$} & \multicolumn{3}{|l|}{ 13. $3 \mathrm{~Pa}$} \\
\hline Plasma polymerization film & $\begin{array}{l}\text { Dis- } \\
\text { charge } \\
\text { duration } \\
\text { (min) }\end{array}$ & $\begin{array}{l}\text { Thick- } \\
\text { ness } \\
\text { removed } \\
\text { (A) }\end{array}$ & $\begin{array}{l}\text { Etching } \\
\text { rate } \\
(\mathrm{A} / \mathrm{min})\end{array}$ & $\begin{array}{l}\text { Dis- } \\
\text { charge } \\
\text { duration } \\
\quad \text { (min) }\end{array}$ & $\begin{array}{l}\text { Thick- } \\
\text { ness } \\
\text { removed } \\
\text { (A) }\end{array}$ & $\begin{array}{l}\text { Etching } \\
\text { rate } \\
(\mathrm{A} / \mathrm{min})\end{array}$ \\
\hline MMA & 3 & 2500 & 830 & 5 & 2500 & 500 \\
\hline MA & 2 & 2000 & 1000 & 5 & 1000 & 200 \\
\hline $\mathrm{S}$ & 10 & 4000 & 400 & 5 & 2000 & 400 \\
\hline$(\mathrm{MMA}+5 \% \mathrm{TMT})$ & 5 & 2000 & 400 & 5 & 1000 & 200 \\
\hline$(\mathrm{MMA}+50 \% \mathrm{~S})$ & 10 & 5000 & 500 & 10 & 2500 & 250 \\
\hline MMA-(MMA $+5 \%$ TMT) & 5 & 2500 & - & 5 & 1500 & - \\
\hline $\mathrm{MA}-(\mathrm{MMA}+5 \% \mathrm{TMT})$ & 8 & 3000 & - & 10 & 1500 & - \\
\hline$(\mathrm{MMA}+5 \% \mathrm{TMT})-(\mathrm{MMA}+50 \% \mathrm{~S})$ & 15 & 7000 & - & 30 & 5500 & - \\
\hline$(\mathrm{MMA}+5 \% \mathrm{TMT})-(\mathrm{MMA}+10 \% \mathrm{MIPK})$ & 8 & 5000 & - & 10 & 3000 & - \\
\hline MMA-MA-(MMA + 5\% TMT) & 3 & 1500 & - & 8 & 1500 & - \\
\hline MMA-S-(MMA +5\%TMT) & 3 & 1800 & - & 10 & 2500 & - \\
\hline (MMA-S) & 4 & 2500 & 630 & 7 & 2000 & 290 \\
\hline (MMA-S)-(MMA +5\% TMT) & 4 & 2500 & - & 8 & 2000 & - \\
\hline $\mathrm{Cr}$ & - & - & - & 10 & 700 & 70 \\
\hline
\end{tabular}




\section{4. 現像機構に関する新しい試み}

プラズマエッチ現像の効果がその本質に於て電子線の 効果と加算的であることに基づく解像度の低下を回避す る目的で，電子線の効果之異質のものを含む現像プロセ スを求めて二つの試みがなされた。それらは未だ優れた レジストプロセスを完成するに至っていないが，今後の 研究に対して示唆偣む富むのである。

\section{1 繰返し多層構造レジスト}

プラズマ重合によれば多層構造レジストを作るととは 容易である。著者等は Table 5 亿示すでとき 7 種の 3 層繰返しあるいは 2 層繰返しレジストを試みた。電子線 照射後 Table 6 に示すごとさプラズマエッチ条件で現 像した。電子線照射の効果とプラズマエッチの効果は加 算性から大きく外れエッチ速度自体が Fig. 11 の如く 顕著なドーズ依存性を示した。構成層のレジスト特性の 平均值之異なる, このような繰返し多層レジストの特性

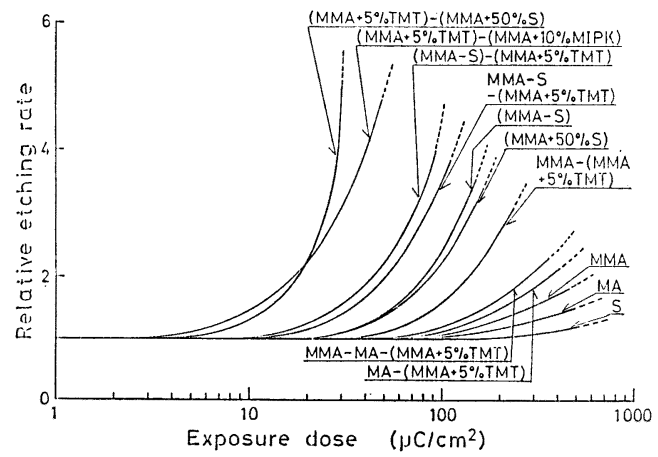

Fig. 11 Effect of plasma etching gas on the film properties. Etching gas; $\mathrm{Ar}+40 \% \mathrm{O}_{2}$.

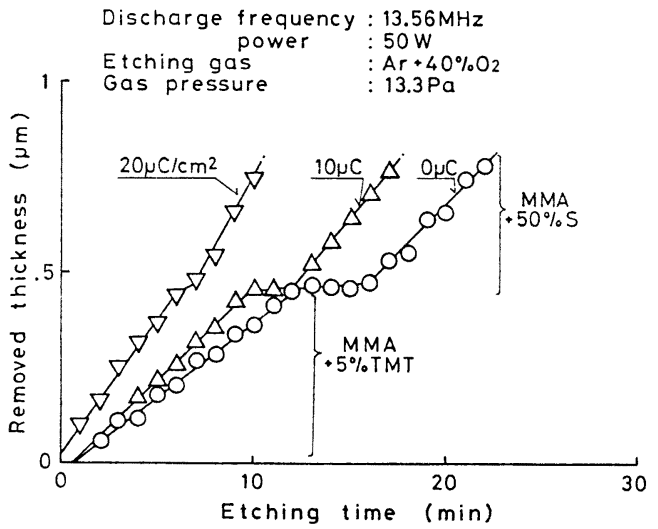

Fig. 12 Plasma etching progress of e-b exposed multilayer resist film including transition layer.
を理解するために，プラズマエッチによる膜減りの状況 をくわしく調べた所, Fig. 12 に示すように構成層の間 には極めて耐エッチ性の高い境界層が形成されて居り, しかも境界層は低ドーズの電子線照射によって消隇する ことがわかった。

\section{2 照射後グラフト反応}

Fig. 1 の装置を用いれば，電子線照射後外気に曝す ことなく分子蒸気中に基板を移すことができる。著者等 は，プラズマ重合醋酸ビニールに電子線照射して後スチ レン蒸気中に設放置した所 Fig. 13 亿示す如く照射部 に膜厚の増加を観察した。乙の膜を酸素プラズマエッチ すると Fig. 14 に示すようなネガ型のレジスト特性が 得られた。50 $\mathrm{C} / \mathrm{cm}^{2}$ の照射で約 $10^{-5} \mathrm{gv} / \mathrm{cm}^{2}$ のグラ フト増量がみられたわけであるから，照射された電子 1 個当り 2 分子のスチレンが捕獲されたことがわかる。

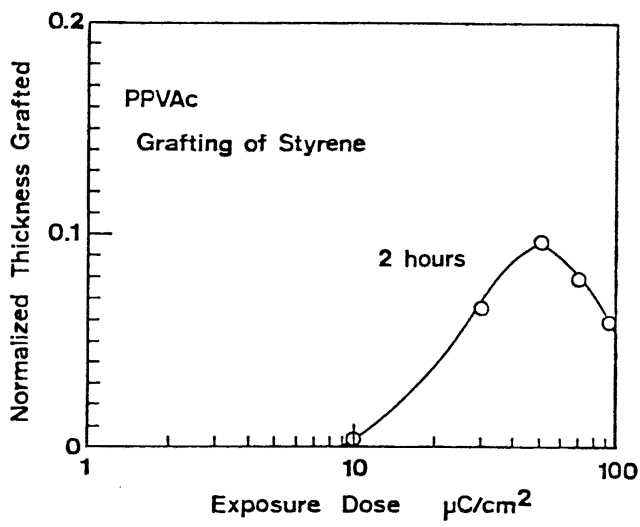

Fig. 13 Film thickness increase of plasmapolymerized vinylacrylate (PPVAc) by after e-b exposure grafting of styrene.

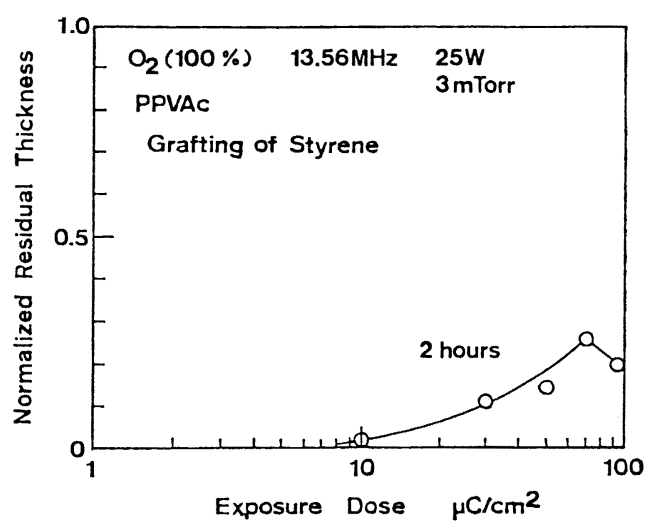

Fig. 14 Plasma development charactaristics of plasma-polymerized vinylacrylate (PPVAc) grafted styrene after e-b exposme. 


\section{5. 今後のドライ現像リソグラフィー}

\section{1 ドライ現像レジストに関する考察}

ポジ電子線あるいはX線レジストに対する溶液現像で は, 主鎖切断によって 60 モノマー程度の中分子量にな ったときに，高分子の分子運動が盛んになることによっ て溶媒分子が高分子膜中に拡散し溶解速度が増加する。 ポジホトレジストに於いては光化学反応によって高分子 の溶媒に対する新和力を增し可溶化する。これに対し, ドライ現像が可能となるためには, 最終的に数モノマー の低分子量まで切断を進行させる効果が必要である。

これまでの知見から，次のような効果はドライ現像ホ トレジストあるいはドライ現像X線レジストの実現のた めに利用できることが推測される。i）スチレンのごと き耐エッチ性の高いモノマーについて, 耐エッチ性には 分子量依存性（高分子量で高耐エッチ性）がある。 ii ） 架橋の程度の増加も耐エッチ性を増す。㧫）超薄耐エッ チ層は特異な高エネルギー照射感度を示す。iv）中程度 の分子量では溶媒のみでなく低分子気体の拡散屯盛んに なる。 v ）グラフト反応による 2 次的な性質の変化を利 用する。vi）レジストに吸蔵された低分子の拡散除去む 利用できる。

\section{2 高感度 $X$ 線レジストに関する考察}

Fig. 15 は線源の広がり $D$ にもとづく半影ボケ $\Delta$ とギャップ変動 $d G$ にもとづく位置ずれ $\varepsilon$ とが, 線源 とマスクの距離 $L$, マスクとウエハのギャップ $G$, 照 射領域寸法 $d$ とどのような関係にあるかを示す。これ 等は

$$
\begin{aligned}
& \Delta=D(G / L) \\
& \varepsilon=d G(L / d)
\end{aligned}
$$

の関係で与えられる。 $\Delta$ を小さくるためには $D$ を小 さく $L$ を大きくする必要があるが， $D$ を小さくすると 単位面積当りの電子線入力が大きくなるので冷却能力に あとづく限界がある。対除極を円推状凹みとすることに よって冷却面積を増したものが固定対陰極X線源として は最屯輝度が高く, $3 \mathrm{~mm} \phi に 4 \mathrm{~kW}$ の電子線を照射す ることができた。

電子線入力 $P$ とX線束 $\Phi$ の関係は

$$
\Phi=30 \cdot 10^{-6}\left(P / L^{2}\right)
$$

で与えられ，感度 $s$ と照射時間 $T$ とは

$$
\varepsilon=\Phi T
$$

で結ばれる。これからスループット（秒 $\left./ \mathrm{cm}^{2}\right)$ は

$$
T / A_{0}=\left(30 \cdot 10^{-6}\right)^{-1} P^{-1}(L / d)^{2} s
$$

で与えられる。Table 7 にまとめたように, $2 \mathrm{~mJ} / \mathrm{cm}$ の感度のX線レジストがあれば $0.6 \mathrm{sec} / \mathrm{cm}^{2}$ のスループ ットが得られ固定対陰極X線源で十分なスループットが
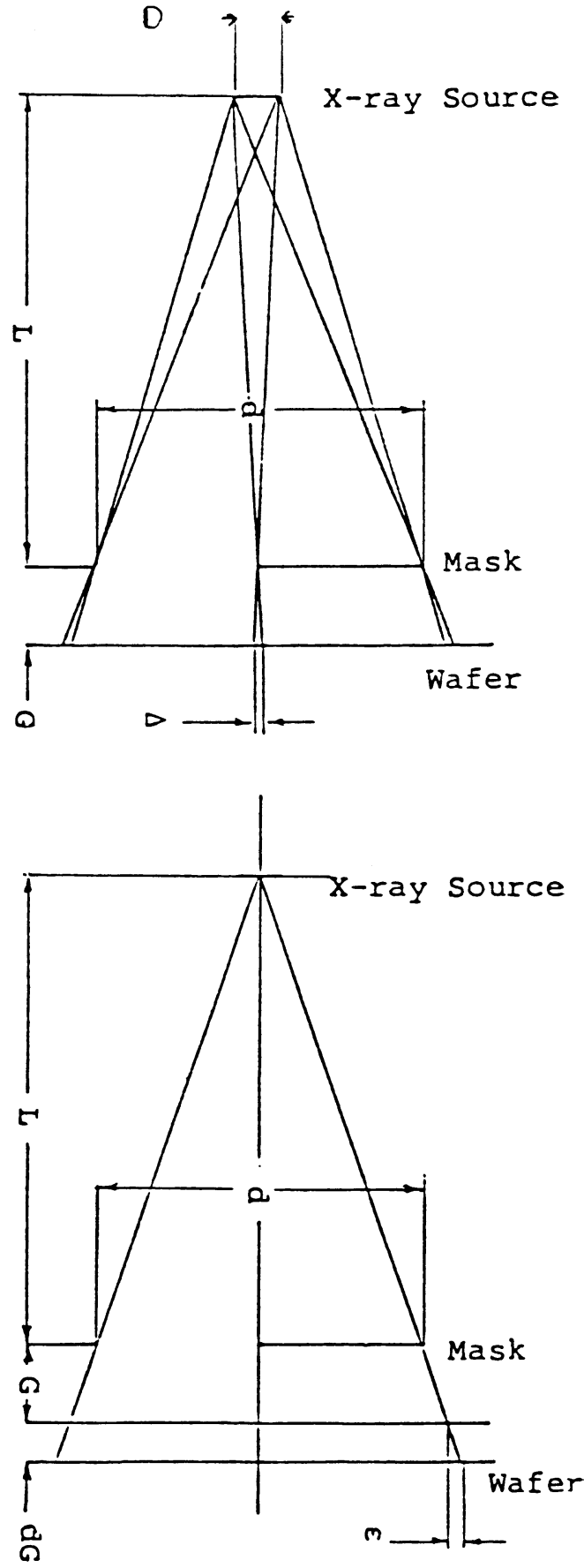

Fig. 15 Origin of diffuse exposure resolution limit $\Delta$ and pattern shift $\varepsilon$ with proximity X-ray lithography.

得られることわがかる。

Table 8 は現在知られているX線レジストの感度を示 す。ネガレジストについては必要な感度に近いものがあ 
Table 7 Requirment for X-ray resist sensitivity.

\begin{tabular}{l}
\hline$\Delta=(G D) / L \quad \Phi=30 \cdot 10^{-6} \cdot P / L^{2} \quad s=\Phi T$ \\
$T / A_{0}=T / n A=\left(30 \cdot 10^{-6}\right)^{-1} P^{-1}(L / d)^{2} s$ \\
$\Delta:$ Nominal Resolution $G:$ Proximity Gap \\
$D:$ Effective Diameter of X-Ray Source \\
$L:$ Distance from Source to Mask \\
$s:$ Sensitivity $\quad \Phi:$ X-Ray Flux \\
$P:$ Electron Beam Power \\
$n:$ Number of Steps $A:$ Area of Exposure \\
$A_{0}:$ Area of Wafer \\
$T:$ Total Exposure Time \\
$(L / d)=6 \quad P=4 \mathrm{~kW} \quad s=2 \mathrm{~mJ} / \mathrm{cm}^{2}$ \\
$T / n A=0.6 \mathrm{sec} / \mathrm{cm}^{2}$
\end{tabular}

Table 9 High sensitivity X-ray resist design.

$$
\begin{aligned}
& \text { High Sensitivity E-Beam Resist } \\
& \begin{array}{ccc}
Q_{e}=(A / M) d \lambda_{v} q /\left(i_{e v} V_{e}\right) & \text { Scission } / \mathrm{eV} \\
& & \\
A=6 \cdot 10^{23} & M=100 & d=10^{-4} \\
q=1.6 \times 10^{-19} & j_{e v}=5.10^{-6} & \lambda_{v}=0.15 \\
Q_{e}=0.14 & V_{e}=2 \cdot 10^{4} &
\end{array}
\end{aligned}
$$

High Sensitivity X-Ray Resist

$$
\begin{array}{ll}
Q_{x}=(A / M) d^{\prime} \lambda_{m} q /\left(J_{x_{m}} V\right) & a=2 \\
Q_{x}=a \cdot Q_{e} & \lambda_{m}=0.015 \\
\left(J_{x m} V_{x}\right)=(A / M) d^{\prime} \lambda_{m} q / Q_{X} & d^{\prime}=4 \times 10^{-4} \\
\left(J_{x m} V_{x}\right)=2 \times 10^{-3} \mathrm{~J} / \mathrm{cm}^{2}
\end{array}
$$

Table 8 Sensitivity and $\gamma$ value of typical negative-working and positive-working $\mathrm{X}$-ray resist.

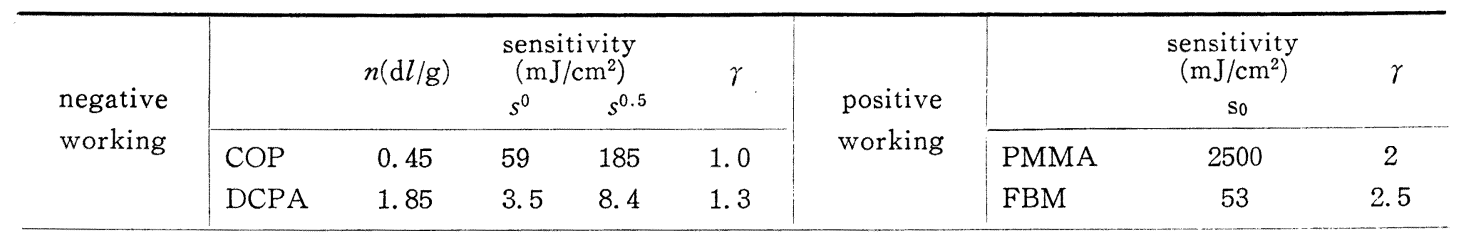

るが，ポジレジストについては 25 倍ほどの感度の増加 が必要である。又ての值は溶液現像についてのものであ るからドライ現像によって $2 \mathrm{~mJ} / \mathrm{cm}^{2}$ の感度を実現する には,さらに 10 倍ほどの感度の増加を必要とする。し かしながら前節の考察はドライ現像でも溶液現像と同じ 程度の分子量低下によって現像完了に至るプロセスを考 えうる可能性を示している。又 25 倍の感度の增加の大 部分は, 電子線レジストの場合と同様重原子による増感 によって達成できうるあのと考えられる。Table 9 は乙 のような考え方でのX線レジスト設計の方針をまとめた 李の゙ある。

\section{6. おわりに}

本稿では著者の研究室に於ける知見以外の知見を十分
紹介することができなかったが，今後の研究に関する考 察には他の研究が参考にされている。又文献を引用する 煩雑を避けた。以下の解説中の文献表を参考にされた い。

○「超 LSI 時代のプラズマ化学」4 章, 8章, (工業 調査会・1983 年)

○「プラズマ反応を応用した新材料創生技術の展開の 可能性に関する調查」(未来工学研究所 1983 年) (科学技術振興調整費による)

○堀勝・服部秀三・森田慎三・谷橋慎太郎「プラズマ 重合メタクリル酸メチル重合機構とレジスト特性評 価」(日化誌 No. 10, 1984) 